ljtihad, Jurnal Wacana Hukum Islam dan Kemanusiaan

Vol. 16, No. 2 (2016), pp. 179-196, doi : 10.18326/ijtihad.v16i2.179-196

\title{
Implementasi prinsip akuntabilitas dalam manajemen wakaf produktif: studi kasus rumah sakit Islam kota Magelang
}

\author{
Nurodin Usman \\ Fakultas Agama Islam Universitas Muhammadiyah Magelang \\ E-mail:nurodin_2000@yahoo.com
}

DOI: 10.18326/ijtihad.v16i2.179-196

This study describes the implementation of the principle of accountability in the management of productive waqf in the form of Islamic Hospital in Magelang City. The results showed that Islamic Hospital is a core business managed by waqfinstitutions and has experienced significant developments with a marked number of users is increasing. The principle of accountability on the Rumah Sakit Islam (Islamic Hospital) Kota Magelang implemented by the Board of Supervisors to supervise routinely based on a report prepared by the Director of RSI. Implementation of this principle on endowments institutions is expected to increase the confidence of stakeholders. For the future, supervision through an external audit needs to be programmed to improve accountability and public trust.

Penelitian ini bertujuan mendeskripsikan implementasi prinsip akuntabilitas pada manajemen wakaf produktif dalam bentuk Rumah Sakit Islam Kota Magelang. Hasil penelitian menunjukkan bahwa RSI Kota Magelang merupakan core bussines yang dikelola lembaga wakaf dan telah mengalami perkembangan yang signifikan dengan ditandai jumlah pengguna yang semakin meningkat. Prinsip akuntabilitas pada RSI Kota Magelang dilakukan melalui Dewan Pengawas yang melakukan pengawasan secara rutin berdasarkan laporan yang disusun oleh Direktur RSI. Implementasi prinsip ini pada lembaga wakaf diharapkan dapat meningkatkan kepercayaan dari stakeholder. Ke depan, pengawasan melalui audit eksternal perlu dilakukan untuk meningkatkan akuntabilitas lembaga di mata masyarakat.

Keywords: Accountability; Productive waqf; Islamic foundation; 
ljtihad, Jurnal Wacana Hukum Islam dan Kemanusiaan, Volume 16, No. 2, Desember 2016: 179-196

\section{Pendahuluan}

Dalam Islam, wakaf merupakan institusi sosial yang telah memberikan pengaruh besar bagi perkembangan peradaban umat Islam. Selain berdimensi ibadah, institusi wakaf memiliki dimensi sosial-ekonomi yang berdampak pemberdayaan umat, khususnya kaum dhu'afa. Institusi wakaf memiliki keistimewaan yang tidak terdapat dalam institusi lain, yaitu berkaitan dengan makna keabadian aset yang dikelola. Dalam konsep wakaf, harta benda wakaf merupakan harta benda yang harus terjaga wujudnya dan tidak boleh berkurang. Sebab, harta wakaf dimaksudkan untuk digunakan hasilnya, bukan bendanya itu sendiri. Pada satu sisi, karakteristik ini menjadi keunggulan konsep wakaf. Dalam perkembangannya, wakaf dapat dibedakan menjadi wakaf istismari (wakaf yang dimaksudkan untuk investasi atau produktif) dan wakaf mubasyir (wakaf yang dimaksudkan untuk dimanfaat secara langsung atau konsumtif).

Dalam konsep wakaf produktif, aset wakaf dikelola dalam bentuk unit-unit usaha atau bisnis yang diharapkan memberi keuntungan bagi lembaga wakaf. Wakaf produktif dimaksudkan sebagai upaya mengelola dan mengembangkan harta wakaf secara produktif dengan tetap memperhatikan kelanggengan harta wakaf dan menyalurkan hasilnya kepada pihak-pihak yang berhak menerima sasaran wakaf. Salah satu wujud nyata dari pengelolaan wakaf produktif adalah apa yang dilakukan oleh Yayasan Kesejahteraan Islam Kota Magelang (selanjutnya disingkat YKI) yang saat ini mengelola Rumah Sakit Islam Kota Magelang dan merencanakan program-program pemberdayaan yang dapat dirasakan manfaatnya secara langsung oleh masyarakat.

Rumah Sakit Islam Kota Magelang merupakan lembaga yang bergerak dalam bidang kesehatan dan didirikan di atas lahan tanah wakaf. Yayasan yang mengelola Rumah Sakit Islam Kota Magelang adalah Yayasan Kesejahteraan Islam (YKI) Kota Magelang. Selain mengelola Rumah Sakit Islam Kota Magelang, Yayasan Kesejahteraan Islam Kota Magelang juga memiliki sejumlah program, seperti Masjid As-Syifa dan lahan wakaf yang akan diberdayakan dalam bidang pendidikan agama Islam.

Yayasan Kesejahteraan Islam Kota Magelang telah mengalami dinamika dari segi pengelolaan dan telah berbenah sehingga saat ini berhasil menyelenggarakan lembaga kesehatan yang diakui masyarakat dan mengalami perkembangan yang signifikan dalam hal 
jumlah pengguna (stakeholders). Pada periode sebelumnya, jumlah pasien yang berobat ke RSI Kota Magelang masih terbatas dan berdasarkan keterangan dari Manajer RSI, yaitu Bapak Saelan, sampai dengan tahun 2009, jumlah pasien RSI dapat dihitung dengan jari. Namun, berkat pembenahan manajerial, jumlah pasien di RSI saat ini mengalami peningkatan yang signifikan. Prosentase pemakaian tempat (bed) di RSI saat ini mencapai lebih dari 60 persen. Perubahan dalam manajerial dan kenaikan yang signifikan dalam penggunaan jasa rumah sakit ini yang menimbulkan sederet asumsi mengenai peningkatan kepercayaan masyarakat terhadap kualitas layanan di rumah sakit.

Penelitian ini difokuskan pada pengelolaan wakaf produktif dalam bentuk Rumah Sakit Islam Kota Magelang yang secara khusus ditinjau dari segi penerapan prinsip akuntabilitas dalam menjalankan manajemen rumah sakit. Pertanyaan dalam penelitian ini dirumuskan sebagai berikut: Bagaimanakah implementasi prinsip akuntabilitas pada manajemen wakaf produktif? Berdasarkan pertanyaan tersebut, tujuan dari penelitian ini adalah untuk mendeskripsikan implementasi prinsip akuntabilitas pada manajemen wakaf produktif dalam bentuk Rumah Sakit Islam Kota Magelang. Kontribusi yang diharapkan dari penelitian ini adalah dapat memberikan bukti empiris bahwa prinsip akuntabilitas sebagai salah satu prinsip dari konsep good coorporate governance merupakan bentuk tanggung jawab lembaga wakaf terhadap stakeholder. Selain itu, implementasi prinsip ini juga merupakan strategi lembaga wakaf yang dapat menjadi strategi untuk mewujudkan tata kelola wakaf yang dapat dipertanggungjawabkan sehingga dapat mengurangi persoalan-persoalan manajerial dan konflik-konflik internal yang dimungkinkan terjadi kelak di kemudian hari. Prinsip akuntabilitas diharapkan menjadi strategi impression management bagi lembaga wakaf dalam membentuk reputasi lembaga sehingga dapat menjadi value creation atau penciptaan nilai yang dapat meningkatkan trust dan signal positif bagi calon wakif untuk mengembangkan lembaga.

\section{Studi pustaka dan kerangka teori}

Penelitian tentang wakaf banyak dilakukan para peneliti, baik di Indonesia maupun di negara lain. Negara-negara muslim yang telah berhasil menerapkan wakaf produktif dan menjadi rujukan bagi para peneliti wakaf diantaranya Mesir, Turki, Malaysia, Arab Saudi, Kuwait, dan sejumlah negara teluk. Bahkan negara miskin, seperti Bangladesh dan Sudan, juga termasuk 
ljtihad, Jurnal Wacana Hukum Islam dan Kemanusiaan, Volume 16, No. 2, Desember 2016: 179-196

dalam negara yang memiliki tata kelola wakaf yang dikenal baik. Sejumlah nama pakar muncul ke permukaan karena kontribusinya dalam bidang wakaf, yaitu Munzir Qahaf dan al-Kabisi. Dari segi lembaga, nama Al-Azhar di Cairo dan al-Amanah al-Ammah li alAwqaf di Kuwait telah dikenal sebagai lembaga wakaf yang kredibel.

Di Indonesia, perkembangan wakaf telah mengalami transformasi dari paradigma wakaf konsumtif menuju paradigma wakaf produktif. Banyak lembaga yang pada akhir-akhir ini menjadi obyek penelitian tentang wakaf, seperti Badan Wakaf UII, Pondok Modern Gontor, Bandha Wakaf Masjid Agung Semarang, Tabung Wakaf Indonesia, dan lembaga-lembaga wakaf yang dikelola oleh organisasi-organisasi keagamaan seperti NU dan Muhammadiyah.

Penelitian tentang manajemen investasi wakaf pernah dilakukan Rozalinda (2010) pada saat menyusun penelitian Disertasi pada Sekolah Pascasarjana Universitas Islan Negeri (UIN) Syarif Hidayatullah dengan judul Pengelolaan Wakaf Uang: Studi Kasus pada Tabung Wakaf Indonesia (TWI) Dompet Dhuafa Republika. Usman melakukan penelitian disertasi (2013) dengan judul Model Pengelolaan dan Pengambangan Bandha Wakaf Masjid Agung Semarang di IAIN Walisongo Semarang.

Penelitian tentang akuntabilitas wakaf pernah dilakukan oleh Arif Budiman (2016) dengan judul Akuntabilitas Lembaga Wakaf yang melakukan penelitian di Rumah Sakit Roemani Semarang, Pos Keadilan Peduli Ummat, dan Yayasan Badan Wakaf Sultan Agung Semarang. Penelitian ini berusaha menggali dan menganalisis data tentang akuntabilitas pengelolaan wakaf produktif dalam bentuk Rumah Sakit Islam Kota Magelang.

Prinsip akuntabilitas merupakan salah satu prinsip manajemen yang harus diimplementasikan pada tata kelola yang baik (good governance). Akuntabilitas erat kaitannya dengan transparansi. Transparansi dalam kontek Good Corporate Governance dimaksudkan untuk menjaga obyektifitas perusahaan dalam menjalankan bisnisnya. Perusahaan harus menyediakan beragam informasi yang bersifat material, memadai, akurat, relevan, dan kepada setiap stakeholder yang membutuhkan informasi-informasi tersebut. Informasi yang memadai, akurat, dan terpercaya sangat diperlukan oleh para investor untuk menyusun langkah-langkah bisnis mereka berkaitan dengan kondisi perusahaan tersebut. Sebaliknya, informasi yang tidak transparan menyebabkan banyak pihak tidak dapat mengakses berbagai informasi yang diperlukan sehingga dapat menyulitkan pihak-pihak luar untuk melihat apakah 
perusahaan tersebut dalam keadaan sehat atau bermasalah. Informasi yang tidak memadai dan tidak akurat dapat menyulitkan para investor dalam memprediksi nilai dan risiko dari modal yang mereka investasikan (Sutedi, 2011: 11).

Selain bersifat akurat, informasi-informasi penting yang berkaitan dengan perusahaan tersebut juga harus disampaikan pada waktu yang tepat. Informasi yang disampaikan pada waktu yang tidak tepat dapat menimbulkan kesalahan dalam prediksi dan pengambilan keputusan (Sedarmayanti, 2007: 56).

Selain itu, informasi-informasi tersebut harus dapat diakses dan dipahami dengan mudah oleh para pemangku kepentingan (stakeholders). Agar hal itu dapat dicapai, perusahaan harus mengambil langkah-langkah inisiatif untuk mengungkapkan informasi-informasi yang berkaitan dengan kepatuhannya terhadap peraturan perundang-undangan dan masalahmasalah penting lainnya bagi proses pengambilan keputusan oleh para pemegang saham, kreditur, dan pemangku kepentingan lainnya. Sebagai contoh, kebijakan-kebijakan perusahaan harus tertulis dan secara proporsional dikomunikasikan dengan berbagai pihak yang berkepentingan dengan perusahaan tersebut (Binhadi, 2006: 5).

Menurut Komisi Nasional Kebijakan Governance, sejumlah informasi yang harus disediakan sebuah perusahaan secara transparan adalah visi, misi, sasaran usaha, strategi perusahaan, kondisi keuangan, susunan dan kempensasi pengurus, pemegang saham, kepemilikan saham oleh anggota Direksi dan anggota Dewan Direksi beserta anggota keluarganya dalam perusahaan dan perusahaan lainnya, sistem manajemen resiko, sistem pengawasan dan pengendalian internal, sistem dan pelaksanaan GCG serta tingkat kepatuhannya, dan kejadian-kejadian penting yang dapat mempengaruhi kondisi perusahaan (Binhadi, 2006: 5).

Sedangkan prinsip akuntabilitas, perusahaan dituntut mampu mempertanggungjawabkan kinerjanya secara transparan dan wajar. Agar hal itu dapat tercapai, menurut KNKG dalam Binhadi (2006: 6), perusahaan harus dikelola secara benar, terukur, dan sesuai dengan kepentingan perusahaan dengan tetap memperhitungkan kepentingan pemegang saham dan stakeholders lainnya.

Dalam Good Corporate Governance, tanggung jawab manajemen dilakukan melalui pengawasan yang efektif berdasarkan keseimbangan kekuasaan antara manajer, pemegang 
saham, dewan komisaris, dan auditor. Jika keseimbangan kekuasaan antara pihak-pihak yang terkait dengan perusahaan tersebut tidak terjadi, dimungkinkan perusahaan tersebut tidak accountable (Sedarmayanti, 2007: 56).

Sebuah perusahaan dikatakan tidak accountable jika ada kontrol yang kuat dari sebagian kecil pemegang saham atau pemilik keluarga terhadap jalannya perusahaan. Prinsip ini menjadi tidak terpenuhi pada sebuah perusahaan yang menerapkan semacam pembagian kekuasaan antara manajer perusahaan dan pemegang saham yang diwakili oleh dewan direksi atau adanya manajemen perusahaan yang duduk dalam dewan direksi sehingga berpotensi KKN (Sutedi, 2011: 11).

Agar kinerja masing-masing unit dapat terukur, menurut KNKG dalam Binhadi (2006: 6), perusahaan harus menetapkan rincian tugas dan tanggung jawab masing-masing unit atau organ dalam perusahaan, termasuk seluruh karyawan, secara jelas dan selaras dengan visi, misi, nilai-nilai perusahaan (corporate values), dan strategi perusahaan. Selain itu, perusahaan juga harus memastikan adanya sistem pengendalian internal yang efektif dalam pengelolaan perusahaan. Perusahaan juga harus menetapkan ukuran yang jelas bagi kinerja masing-masing organ perusahaan dan sistem penghargaan dan sanksi (reward and punishment system) bagi seluruh anggota unit perusahaan yang berhak mendapatkannya.

Menurut Budiman (2011), akuntabilitas merupakan proses dimana suatu lembaga menganggap dirinya bertanggung-jawab secara terbuka mengenai apa yang dilakukan dan tidak dilakukannya. Secara operasional akuntabilitas diwujudkan dalam bentuk pelaporan (reporting), pelibatan (involving), dan cepat tanggap (responding). Akuntabilitas bukan sematamata berhubungan dengan pelaporan keuangan dan program yang dibuat, melainkan berkaitan pula dengan persoalan legitimasi publik.

Dalam penelitian ini, prinsip akuntabilitas akan diimplementasikan pada lembaga yang mengelola aset wakaf produktif. Secara etimologi, kata wakaf berasal dari bahasa Arab, yaitu "al-waqf" yang berarti menahan sesuatu dari konsumsi dan melarang seluruh manfaat atau keuntungan dari selain pihak yang menjadi sasaran wakaf (Qahaf, 2006: 55). Dalam fikih kontemporer, definisi wakaf dijelaskan oleh Nazih Hammad dan Munzir Qahaf. Nazih Hammad, (1995: 353) mendefinisikan wakaf sebagai akad menahankan aset wakaf dan menyalurkan manfaatnya pada sabilillah. Munzir Qahaf (2006: 62) mendefinisikan wakaf 
yaitu akad menahan harta, baik bersifat selamanya maupun untuk jangka waktu tertentu, agar diambil manfaatnya secara berulang-ulang, dari harta tersebut atau dari hasilnya, untuk keperluan kebaikan, baik yang bersifat umum maupun khusus.

Dalam Undang-Undang Nomor 41 Tahun 2004, wakaf diartikan dengan perbuatan hukum wakif untuk memisahkan dan/atau menyerahkan sebagian harta benda miliknya untuk dimanfaatkan selamanya atau untuk jangka waktu tertentu sesuai dengan kepentingannya guna keperluan ibadah dan/atau kesejahteraan umum menurut syariah. UU Wakaf tersebut juga memunculkan istilah baru yang disebut dengan unsur-unsur wakaf. Berdasarkan UU ini, unsur-unsur wakaf terdiri dari sigah atau ikrar wakaf, wakif (orang yang berwakaf), manquf(harta benda wakaf), mauquf'alaih (penerima manfaat wakaf), nazhir (pengelola wakaf), dan jangka waktu wakaf.

Dalam kaitannya dengan penggunaan dan produktifitas wakaf, wakaf dapat dibedakan menjadi wakaf mubasyir dan wakaf istismari. Wakaf mubasyir adalah harta wakaf yang menghasilkan pelayanan masyarakat dan bisa digunakan secara langsung seperti madrasah dan rumah sakit. Sedangkan wakaf istismari adalah harta wakaf yang ditujukan untuk penanaman modal dalam produksi barang-barang dan pelayanan yang dibolehkan syara' dalam bentuk apapun kemudian hasilnya diwakafkan sesuai keinginan wakif. Wakaf istismari biasa disebut juga wakaf produktif, yaitu wakaf harta yang digunakan untuk kepentingan investasi, baik di bidang pertanian, perindustrian, perdagangan, dan jasa. Manfaat pada wakaf produktif tidak diperoleh dari benda wakaf secara langsung, melainkan dari keuntungan atau hasil pengelolaan wakaf.

Kata produktif merupakan kata sifat yang berasal dari kata produk yang berarti hasil, hasil kerja, barang atau benda yang dihasilkan (al-Barry, 2003: 633). Berdasarkan makna tersebut, kata produktif memiliki pengertian sesuatu yang memiliki daya hasil atau mempunyai kemampuan untuk menghasilkan (dalam jumlah besar). Makna lain dari kata produktif adalah subur (al-Barry, 2003: 633). Jaih Mubarok (2008: 16) mengartikan wakaf produktif sebagai proses pengelolaan benda wakaf untuk menghasilkan barang atau jasa yang maksimum dengan modal yang minimum. Menurut Mubarok (2008: 28), wakaf produktif dikelola dengan pendekatan bisnis, yakni suatu usaha yang berorientasi pada keuntungan dan keuntungan tersebut disedekahkan kepada pihak yang berhak menerimanya. Tujuan 
ljtihad, Jurnal Wacana Hukum Islam dan Kemanusiaan, Volume 16, No. 2, Desember 2016: 179-196

utama bisnis adalah laba atau keuntungan melalui berbagai usaha yang mampu menghasilkan barang dan jasa yang dibutuhkan masyarakat. Berbagai usaha yang termasuk kegiatan bisnis meliputi usaha pertanian, produksi, konstruksi, distribusi, transportasi, komunikasi, usaha jasa, dan pemerintahan yang bergerak dalam bidang membuat dan memasarkan barang dan jasa kepada konsumen (Alma, 2009: 115).

Menurut Antonio dalam Mubarok (2008: 35), wakaf produktif adalah pemberdayaan wakaf yang ditandai dengan tiga ciri utama, yaitu pola manajemen yang intergratif, mengikuti asas kesejahteraan nazhir, dan asas transparansi dan tanggung jawab. Pola manajemen wakaf integratif berarti memberi peluang bagi dana wakaf untuk dialokasikan kepada programprogram pemberdayaan dengan segala macam biaya yang tercakup didalamnya. Asas kesejahteraan nazhir menuntut pekerjaan nazhir tidak lagi diposisikan sebagai pekerja sosial, tetapi sebagai professional yang bisa hidup layak dari profesi tersebut. sedangkan asas transparansi dan tanggung jawab (accountability) mengharuskan lembaga wakaf melaporkan proses pengelolaan dana kepada umat tiap tahun.

\section{Metode penelitian}

Penelitian ini merupakan penelitian lapangan yang bertujuan mendeskripsikan implementasi prinsip akuntabilitas pada Rumah Sakit Islam Kota Magelang. Aset wakaf yang dijadikan obyek penelitian adalah aset wakaf yang dikelola Yayasan Kesejahteraan Islam Kota Magelang yang terletak di daerah Sanden Kota Magelang. Data yang digali adalah data lapangan yang ada di Rumah Sakit Islam Kota Magelang.

Pendekatan yang dipakai dalam penelitian ini adalah pendekatan manajemen. Menurut Putra (2013: 102), penelitian kualitatif manajemen dilakukan untuk menggali makna yang dihayati oleh para pengelola (manajer) dalam menjalankan fungsi-fungsi manajemen, prosesproses dalam pengambilan keputusan, sistem pengawasan, aspek kepemimpinan, dan aspekaspek manajemen lainnya.

Teknik pengumpulan data dilakukan melalui observasi, wawancara, dan dokumentasi. Obyek yang diamati adalah obyek yang berkaitan dengan pengelolaan Rumah Sakit, baik yang berkaitan dengan bangunan fisik maupun model pelayanan terhadap stakeholders. Wawancara dilakukan secara terbuka, baik dengan pedoman maupun tanpa pedoman 
(Bungin, 2008: 108), terhadap para pengelola Rumah Sakit untuk menggali berbagai macam informasi yang berkaitan dengan model pengelolaan Rumah Sakit. Teknik dokumentasi dilakukan untuk melihat dan menyelidiki data-data tertulis yang terkait dengan pengelolaan Rumah Sakit seperti data-data historis berupa surat-surat keputusan yang berkaitan dengan Rumah Sakit Islam Kota Magelang, dokumen mengenai program kerja, laporan-laporan kegiatan, maupun data-data tertulis lainnya yang diperoleh secara langsung dari para pengelola. Data yang telah berhasil digali selanjutnya dianalisis dengan menggunakan metode analisis deskriptif kualitatif. Proses analisis dilakukan sejak pengumpulan data (Sugiyono, 2008: 337) untuk memahami, menelaah, mendalami, dan menginterpretasikan fenomena yang muncul terkait aktifitas pengelolaan Rumah Sakit untuk selanjutnya ditarik sebuah kesimpulan.

Proses analisis data dilakukan melalui serangkaian aktifitas yang saling berkaitan, yaitu reduksi data, penyajian data, dan verifikasi untuk ditari sebuah kesimpulan (Emir, 2012: 133). Kesimpulan diwujudkan dalam bentuk statemen-statemen mengenai model pengelolaan wakaf dalam bentuk Rumah Sakit Islam Kota Magelang yang merupakan jawaban bagi pertanyaan yang dirumuskan dalam masalah penelitian ini. Tahapan-tahapan tersebut bersifat dinamis dan merupakan satu kesatuan yang utuh yang digunakan dalam menganalisis datadata dalam penelitian ini.

\section{Profil rumah sakit Islam kota Magelang}

Rumah Sakit Islam Kota Magelang merupakan Rumah Sakit Islam satu-satunya di Kota Magelang hingga saat ini. Ide rumah sakit ini diawali oleh keinginan beberapa orang yang bermaksud untuk mendirikan lembaga keagamaan yang dapat dirasakan manfaatnya oleh banyak orang. Ide tersebut ditindaklanjuti dengan pembelian sebidang tanah seluas $2250 \mathrm{~m}^{2}$. Pada mulanya, tanah tersebut akan digunakan untuk membangun lembaga pendidikan atau sekolah. Akan tetapi dalam perkembangannya, opsi untuk mendirikan lembaga pendidikan tersebut beralih ke opsi sebuah lembaga yang melayani kesehatan atau rumah sakit. Rencana untuk mendirikan rumah sakit tercetus atas dasar pandapat pada waktu itu bahwa masyarakat yang bermaksud berobat ke rumah sakit banyak yang terkendala masalah biaya.

Dengan bermodalkan tekad yang kuat para pendiri berusaha untuk mewujudkan citacita itu. Namun karena mendirikan rumah sakit perlu modal yang besar, langkah pertama 
yang dilakukan adalah membentuk tim kecil untuk menggalang pencarian dana. Tim kecil tersebut segera melakukan koordinasi dan dalam berkembangannya merubah bentuk menjadi sebuah yayasan. Hal ini dilakukan karena dalam sistem perundang-undangan kita, pihak yang bisa melakukan pengumpulan dan penarikan dana baik wakaf, hibah, atau sedekah jariyah adalah sebuah badan atau lembaga dan bukan pribadi atau individu. Yayasan tersebut selanjutnya diberi nama Yayasan Kesejahteraan Islam Kota Magelang dan disahkan berdasarkan Akta Notaris Kunsri Hastuti, SH., pada hari Rabu, 4 Agustus 1993.

Dalam Akta Notaris tersebut dinyatakan bahwa maksud dan tujuan Yayasan Kesejahteraan Islam Kota Magelang (selanjutnya disebut YKI) meliputi tiga bidang, yaitu bidang sosial, keagamaan, dan kemanusiaan. Visi YKI yang dirumuskan adalah mewujudkan masyarakat yang madani sedangkan misinya adalah menyelenggarakan pelayanan sosial, mengembangkan syiar Islam, dan menyelenggarakan pelayanan kemanusiaan. Akta tersebut juga menyebutkan nama-nama pendiri yayasan yang berjumlah 13 orang terdiri dari beberapa unsur masyarakat, seperti dokter, tokoh agama, birokrat, dan tokoh masyarakat.

Dalam bidang sosial, YKI berusaha menyelenggarakan kegiatan berupa Rumah Sakit Islam Kota Magelang, Poliklinik, Laboratorium, lembaga pendidikan formal dan non formal, panti asuhan, panti jompo, panti wreda, penelitian di bidang ilmu pengetahuan, dan studi banding. Dalam bidang keagamaan, kegiatan yang dilaksanakan adalah mendirikan sarana ibadah, menyelenggarakan pondok pesantren dan madrasah, menerima dan menyalurkan amal zakat, infaq dan sedekah, meningkatkan pemahaman keagamaan, melaksanakan syiar keagamaan, dan studi banding keagamaan. Dalam bidang kemanusiaan, kegiatan yang dilaksanakan adalah memberi bantuan kepada korban bencana alam, memberi bantuan kepada tuna wisma, fakir miskin, gelandangan, kaum dhuafa, dan melestarikan lingkungan hidup.

Program pertama yang selanjutnya menjadi ikon yayasan adalah mendirikan rumah sakit yang diberi nama Rumah Sakit Islam Kota Magelang. Langkah awal yang dilakukan pendiri adalah menggalang dana yang dijadikan sebagai modal awal berdirinyya rumah sakit. Penggalangan dana tersebut dilakukan melalui berbagai cara, diantaranya menghimpun dana dari pendiri dengan cara menyisihkan rejekinya setiap bulan, mengajukan proposal ke lembagalembaga atau perorangan untuk mendapatkan bantuan, menjual piagam sertifikat kavling 
tanah dengan nominal harga tanah per lembar sertifikat yang bervariasi, dan menggalan dana atau bantuan yang sifatnya tidak mengikat.

Setelah dana terkumpul, langkah berikutnya adalah membeli tanah yang akan dijadikan sebagai lokasi rumah sakit. Tanah yang berhasil dimiliki oleh YKI pada periode ini adalah tanah membeli tanah seluas $2.250 \mathrm{~m}^{2}$ dan $4.750 \mathrm{~m}^{2}$. Setelah mendapatkan tanah, Yayasan berusaha mendirikan/mengupayakan berdirinya gedung. Gedung atau bangunan Rumah Sakit Islam itu sendiri tentunya membutuhkan dana yang tidak sedikit sehingga para pendiri berusaha mencari dana dari sumber-sumber yang halal dan tidak mengikat. Pada tahun 1996, YKI mendapatkan bantuan dana dari berbagai pihak yang digalang oleh Fuad Bawazier dan digunakan untuk membangun gedung utama rumah sakit dan bangunan pendukungnya. Selanjutnya, para pendiri berusaha memenuhi fasilitas, sarana, dan prasarana yang mendukung beroperasinya sebuah rumah sakit. Untuk memenuhi kebutuhan tersebut, para pendiri berusaha menggalang dana dari berbagai pihak sehingga banyak umat Islam, baik atas nama pribadi maupun atas nama lembaga, turut berpartisipasi bagi berdirinya Rumah Sakit Islam Kota Magelang tersebut. Sedangkan untuk mendukung operasional rumah sakit, terutama untuk menggaji tenaga medis dan perawat, para pendiri melakukan iuran rutin setiap bulan sebesar Rp. 200.000,- dan membayarkan Zakat Mal mereka ke Rumah Sakit Islam.

Demikianlah sejarah awal berdirinya RSI Kota Magelang yang diwarnai dengan banyak pengorbanan dari para pendiri. Dalam perkembangannya, bangunan fisik dan fasilitas rumah sakit terus mengalami perkembangan. Yayasan juga berhasil menambah tanah seluas 1.000 $\mathrm{m}^{2}$ untuk pembangunan Masjid. Tanah tersebut dibeli dari hasil wakaf umat Islam di sekitar Rumah Sakit. Sedangkan untuk pembangunan masjid, pengelola Yayasan berusaha mendapat bantuan dari Yayasan Amal Bakti Muslim Pancasila melalui Fuad Bawazier. Peletakan batu pertama pembangunan Masjid dilakukan bersamaan dengan Peresmian Rumah Sakit Islam Kota Magelang, yaitu pada tanggal 6 Juni 1997 oleh Menteri Kesehatan Republik Indonesia Bapak Prof. Dr. H. Sujudi.

Pada tahun 2000 Yayasan menambah gedung untuk memenuhi persyaratan pengajuan ijin tetap Rumah Sakit Islam antara lain harus ada 50 bed/tempat tidur. Dana pembangunan beserta alat perlengkapan pasien berasal dari dana hasil usaha Rumah Sakit dan amal jariyah umat Islam. Pada tahun 2004, Yayasan membeli sejumlah tanah dan bangunan. Pada tahun 
2008, RSI melengkapi fasilitas Rumah Sakit dengan menambah peralatan Rontgen, USG, dan peralatan medis/non medis lainnya.

Dalam perkembangannya Yayasan Kesejahteraan Islam Kota Magelang telah mengalami beberapa kali pergantian pengurus dan kegiatannya masih pada rumah sakit dan kegiatan keagamaan, yaitu dengan dibangunnya masjid Asy-Syifa'. Rumah Sakit Islam Kota Magelang berperan sebagai rumah sakit umum yang memberikan pelayanan kesehatan tingkat skunder bagi masyarakat kota Magelang dan sekitarnya yang terdiri dari pelayanan rawat jalan, rawat inap, pemeriksaan penunjang medik (radiologi dan patologi klinik) serta tindakan medis yang dalam operasionalnya berdasarkan izin sementara yang berakhir pada tahun 2011.

Dalam upayanya untuk memperoleh izin tetap dan penetapan kelas rumah sakit, Rumah Sakit Islam Kota Magelang telah mendapat peninjauan (visitasi) dari Dinas Kesehatan Provinsi Jawa Tengah Sub Bagian Pelayanan pada bulan Februari 2012. Dari hasil visitasi tersebut, diperoleh rekomendasi berupa persyaratan yang harus dipenuhi oleh Rumah Sakit Islam Magelang, agar dapat memperoleh Surat Izin Tetap dan Klasifikasi Rumah Sakit Tipe D. Saat ini Rumah Sakit Islam Magelang ditunjuk oleh PT Askes Cabang Magelang untuk melayani peserta Askes dan keluarganya dirawat inap untk kelas I dan II. Demikian juga Rumah Sakit Islam Kota Magelang ditunjuk oleh Dinas Kesehatan Kota Magelang untuk melayani peserta Jamkesmas Kota Magelang. Terakhir tahun 2014 semua rumah sakit baik milik pemerintah maupun swasta termasuk Rumah Sakit Islam Kota Magelang diharuskan untuk mampu menerima peserta asuransi Badan Penyelenggaran Jaminan Sosial (BPJS). Untuk keperluan tersebut di atas, Rumah Sakit Islam Kota Magelang harus segera melakukan pengembangan dan perbaikan di segala bidang, terutama membangun dan mengembangkan ruang perawatan yang saat ini baru ada 48 tempat tidur, membuat master plan rumah sakit sebagai pedoman pengembangan secara keseluruhan, meningkatkan dan mempercepat proses pelayanan, meningkatkan loyalitas dan kebanggaan karyawan terhadap Rumah Sakit Islam Kota Magelang dan meningkatkan kinerja Rumah Sakit Islam Kota Magelang agar menjadi efisien dan efektif.

Tujuan ditetapkannya Peraturan Kepegawaian ini adalah untuk meningkatkan prestasi dan gairah kerja, sehingga bekerja dapat dirasakan sebagai kebutuhan yang mesti dilaksanakan sebaik-sebaiknya, dan meningkatkan pelayanan yang bersifat humanis dengan memperhatikan kebutuhan jasmani, rohani, dan sosial. Dengan adanya peraturan kepegawaian ini diharapkan 
hubungan kerja antara Yayasan dengan pegawai, baik tenaga medis maupun tenaga non medis, maupun antar pegawai, dapat terbina dengan baik untuk lebih meningkatkan kualitas pelayanan di bidang kesehatan kepada masyarakat luas.

\section{Implementasi prinsip akuntabilitas pada RSI}

Menurut Budiman (2011) persoalan transparansi dan akuntabilitas merupakan hal terpenting dalam menjalankan aktivitas lembaga wakaf. Di lapangan, lembaga-lembaga wakaf menerapkan sistem yang berbeda-beda dalam mengedepankan aspek transparansi dan akuntabilitas ini. Mekanisme pertanggungjawaban kepada masyarakat yang dilakukan lembaga wakaf dapat disimpulkan menjadi dua model, yaitu: model legalisme dan model komunalisme. Akuntabilitas model legalisme mengacu pada model pengungkapan berbagai informasi organisasi karena adanya regulasi yang mendorong pengungkapan pelaporan keuangan lembaga nirlaba lewat aturan-aturan yang berlaku. Implementasi akuntabilitas model ini diwujudkan dengan dilakukannya auditing menggunakan auditing internal di lembaga tersebut, sekaligus melakukan auditing eksternal dengan menggunakan akuntan publik.

Sedangkan akuntabilitas model komunalisme merujuk pada mekanisme pengungkapan data dan informasi yang dimiliki organisasi dengan melibatkan masyarakat. Pelibatan (involving) pihak-pihak terkait (stakeholders) dalam pengelolaan wakaf merupakan langkah yang tepat untuk mempertahankan kepercayaan publik terhadap lembaga itu. Lewat mekanisme semacam ini, pelibatan dan kontrol masyarakat terhadap kinerja organisasi bisa dilakukan secara optimal. Model ini diajukan sebagai bentuk alternatif terhadap model lain (legalisme dan assosiatisme) yang dianggap belum mencerminkan transparansi secara utuh dan mudah dimanipulasi, meski sistem yang digunakan sudah cukup rapi dan menggunakan tenaga audit yang profesional.

Penerapan prinsip akuntabilitas di RSI lebih dekat dengan model legalisme. Pengawasan melalui jalur legal dan organisatoris lebih dominan dalam pengelolaan yayasan. Sebagai lembaga yang dibangun atas dasar dana wakaf, akuntabilitas dengan menggunakan model komunalisme bisa jadi merupakan kebutuhan pada masa-masa yang akan datang.

Banyak langkah yang dapat ditempuh oleh Pengelola RSI untuk mewujudkan tata kelola yang akuntabel. Implementasi prinsip ini dapat merujuk pada lembaga lembaga wakaf 
sejenis, yaitu yang bergerak pada bidang layanan kesehatan. Dalam penelitiannya tentang prinsip akuntabilitas pada Rumah Sakit Roemani di Semarang, Budiman (2011) menyimpulkan bahwa implementasi prinsip akuntabilitas pada RS Roemani dilakukan melalui kegiatan auditing yang dilakukan oleh auditor internal dan auditor eksternal. Audit eksternal terhadap pengelolaan wakaf RS Roemani dilakukan oleh akuntan publik dan audit internal dilakukan setiap tahun oleh Muhammadiyah melalui lembaga yang diberi otoritas melakukan audit. Kegiatan ini dimaksudkan untuk menumbuhkan iklim yang kondusif dalam mengelola wakaf produktif di RS Roemani. Tujuan audit diantaranya untuk menyatakan penilaian atas kewajaran yang menyangkut; posisi keuangan, hasil usaha, dan arus kas yang sesuai dengan prinsip akuntansi. Auditing merupakan proses manajemen yang penting, dan akan berimplikasi pada meningkatnya kepercayaan masyarakat.

Kegiatan auditing yang dilakukan oleh akuntan publik diharapkan dapat mewujudkan objektifitas dalam pengawasan lembaga. Selain itu, kegiatang auditing, baik secara internal maupun eksternal, diharapkan dapat mempertahankan dan meningkatkan kepercayaan masyarakat terhadap kinerja lembaga wakaf sehingga dapat menambah wakaf-wakaf baru yang dapat dikelola oleh lembaga tersebut. Dalam manajemen wakaf, kepercayaan publik merupakan sesuatu yang harus dijaga dan dipertahankan karena akan mempengaruhi legitimasi terhadap lembaga pengelola wakaf, yang diukur dari besarnya pengakuan dan dukungan publik kepada lembaga wakaf. Dengan demikian, akuntabilitas bukan semata-mata berhubungan dengan pelaporan keuangan dan program yang dibuat, melainkan berkaitan pula dengan persoalan legitimasi publik (Budiman, 2011).

Dari segi pembinaan dan pengawasan, RSI Kota Magelang memiliki struktur organisasi yang mengikuti struktur pada UU Yayasan, yaitu terdiri dari Dewan Pembina, Dewan Pengurus, dan Dewan Pengawas.

Sesuai dengan namanya, Dewan Pembina bertugas membina organ yang ada di dalam struktur yayasan. Dalam perspektif Dewan Pembina, kedudukan Dewan Pembina adalah "owner" bagi setiap usaha yang ada di yayasan. Sebagai organ yang memiliki struktur ortganisasi tertinggi di yayasan, Dewan Pembina terdiri tujuh orang yang merepresentasikan beberapa unsur, yaitu unsur pendiri, unsur kepakaran dalam bidang agama, unsur kepakaran dalam bidang kedokteran, unsur kepakaran dalam bidang organisasi, dan unsur kepakaran dalam bidang hukum. Banyaknya 
unsur yang ada dalam struktur pembina tersebut diharapkan dapat mengawal kinerja yayasan, membuat kebijakan umum bagi arah atau tujuan yayasan, dan menyatukan persepsi dan langkah setiap organ yayasan agar menuju pada tujuan telah dirumuskan.

Pada tahun 2014, Dewan Pembina mengeluarkan Kebijakan Umum yang menjadi arah perjalanan yayasan dan menjadi pegangan bagi seluruh organ yayasan. Dalam Kebijakan Umum tersebut dinyatakan secara tegas bahwa tujuan yayasan dalam bidang sosial adalah membantu sesama umat dalam pemeliharaan kesehatan dan kegiatan yayasan adalah mendirikan dan mengelola Rumah Sakit Islam Kota Magelang sesuai Undang-Undang tentang Rumah Sakit (Pasal 3 ayat 1 dan 2).

Kebijakan Umum memberikan amanat kepada Pelaksana Kegiatan, yaitu Direktur RSI, untuk melaksanakan kewajibannya secara profesional, transparan, dan akuntabel sesuai dengan program kegiatan yang ditetapkan Dewan Pengurus agar dapat mencapai hasil yang optimal, khususnya dalam bidang layanan medik, pengelolaan keuangan, dan pembinaan pegawai.

Pasal 4 ayat (3) Kebijakan Umum mewajibkan Direktur RSI untuk menyusun laporan keuangan setiap tahun anggaran berdasarkan prinsip-prinsip pembukuan yang benar, baik secara bulanan, semester, maupun tahunan, guna disampaikan kepada Pengurus dan Pengawas. Selanjutnya, laporan keuangan tersebut diperiksa oleh Pengawas dan hasilnya disampaikan kepada Pembina untuk dijadikan bahan evaluasi dan tindak lanjut.

Berdasarkan Kebijakan Umum tersebut, keuangan RSI dikelola oleh Direktur RSI sebagai pelaksana dan Direktur memiliki tugas untuk menyusun laporan keuangan RSI secara periodik dan selanjutnya diserahkan kepada Dewan Pengawas untuk menganalisis poisis keuangan yayasan. Pada periode sebelum tahun 2014, pelaporan keuangan RSI dilakukan oleh Direktur setiap tiga bulan sekali sedangkan pada periode 2014 dan seterusnya Dewan Pengurus menargetkan pelaporan keuangan dilakukan setiap bulan. Hanya saja, pada praktiknya hal tersebut belum berjalan dengan lancar seperti yang diharapkan Dewan Pengurus.

Dewan Pengurus bertugas mengelola yayasan dan unit-unit usaha yang ada di bawahnya. Dalam menjalankan tugasnya, Pengurus bertanggung jawab atas anggaran dan rencana kerja kepada Dewan Pembina. Dari segi pembinaan dan pengawasan terhadap RSI Kota Magelang, Dewan Pengurus memiliki hak untuk mengangkat dan memberhentikan pelaksana kegiatan yayasan, yaitu dalam hal ini Direktur Rumah Sakit Islam Kota Magelang. 
Dewan Pengawas merupakan organ Yayasan yang bertugas melakukan pengawasan dan memberi nasihat kepada Pengurus dalam menjalankan kegiatan Yayasan. Dewan Pengawas pada Yasayan yang menaungi RSI Kota Magelang terdiri dari tiga orang yang dianggap memiliki pengalaman dan kemampuan dalam bidang keahlian dan pengalaman yang berkaitan dengan akuntansi dan keuangan sehingga dapat mengawasi pelaksanaan tata kelola yayasan yang baik. Dalam Undang-undang Yayasan, Pengawas berhak mengetahui segala tindakan yang telah dijalankan oleh Pengurus dan dapat memberhentikan untuk sementara Pengurus, apabila Pengurus tersebut bertindak bertentangan dengan Anggaran Dasar dan/atau peraturan perundang-undangan yang berlaku.

Saat ini, RSI Kota Magelang sedang menjalani transformasi manajerial untuk mewujudkan tata kelola rumah sakit yang transparan dan akuntabel. Dalam proses transformasi tersebut, pengelola yayasan sedang mencari model akuntabilitas yang sesuai dengan kondisi RSI pada saat ini. Pengelola Yayasan memiliki tugas untuk mewujudkan lembaga yang mampu menyediakan informasi dan data yang akurat, memadai, relevan, dan mudah diakses oleh pihak-pihak yang berkepentingan dengan yayasan. Kemudahan dalam mengakses informasi ini menjadi penting bagi lembaga publik, apalagi yang dibangun menggunakan dana wakaf, untuk menjaga dan meningkatkan trust dan sebagai bentuk akuntabilitas lembaga kepada masyarakat.

Pengelola yayasan juga harus mampu mewujudkan keseimbangan di antara organ-organ yayasan sehingga tidak terjadi kontrol yang kuat dari sebuah organ terhadap organ lainnya. Adanya kontrol yang kuat dan tidak seimbang dalam sebuah organisasi dapat merusak keseimbangan yang berdampak pada hilangnya kepercayaan sesama organ yayasan.

\section{Penutup}

Hasil penelitian menunjukkan bahwa RSI Kota Magelang merupakan core bussines yang dikelola lembaga wakaf, yaitu Yayasan Kesejahteraan Islam Kota Magelang. RSI Kota Magelang saat ini telah menjadi rumah sakit yang dipercaya di Kota Magelang dan telah mengalami perkembangan yang signifikan dengan ditandai jumlah pengguna yang semakin meningkat.

Dari segi manajerial, RSI Kota Magelang mengalami transformasi yang mengacu kepada Undang-Undang Yayasan. Organ-organ yayasan, yang terdiri dari Dewan Pembina, Pengurus, 
dan Pengawas, bekerja secara dinamis dan bersama-sama mewujudkan tujuan berdirinya yayasan. Dewan Pembina telah menyusun Kebijakan Umum yang menjadi acuan bagi Dewan Pengurus untuk menjalankan roda organisasi yayasan. Sedangkan Dewan Pengurus bertugas mengelola dan mengembangkan yayasan, diantaranya dan yang paling utama adalah menjamin pengolaan RSI berjalan dengan baik, transparan, dan akuntabel. Prinsip akuntabilitas pada RSI Kota Magelang dilakukan melalui Dewan Pengawas yang melakukan pengawasan secara rutin berdasarkan laporan yang disusun oleh Direktur RSI. Implementasi prinsip ini pada lembaga wakaf diharapkan dapat meningkatkan kepercayaan dari stakeholder, khususnya wakif dan calon wakif untuk meningkatkan produktifitas wakaf. Prinsip ini juga merupakan bentuk tanggungjawab lembaga untuk mewujudkan tata kelola wakaf yang baik sehingga dapat mengurangi potensi konflik-konflik internal dan manajerial yang dapat merugikan lembaga itu sendiri.

Permasalahan manajerial yang terjadi di tubuh yayasan dikembalikan kepada Anggaran Dasar dan Kebijakan Umum yang dirumuskan oleh Dewan Pembina. Dengan mekenisme tersebut, RSI diharapkan dapat berkembang dan menjadi rumah sakit yang semakin maju dan dipercaya oleh masyarakat.

\section{Daftar pustaka}

Alma, Buchari, dan Donni Juni Priansa. Manajemen Bisnis Syariah. Bandung: Penerbit Alfabeta, 2009.

Al-Barry, M. Dahlan. Y, dan Yacub, L. Lya Sofyan. Kamus Induk Istilah Ilmiah. Surabaya: Penerbit Target Press, 2003.

Binhadi, dkk. Pedoman Umum Good Corporate Governance Indonesia. Jakarta: Komite Nasional Kebijakan Governance, 2006.

Budiman, Achmad Arif, "Akuntabilitas Lembaga Pengelolaan Wakaf” dalam Walisongo: Jurnal Penelitian Sosial Keagamaan Vol. 19, No. 1 (2011): pp. 75-102.

Bungin, M. Burhan. Penelitian Kualitatif: Komunikasi, Ekonomi, Kebijakan Publik, dan Ilmu Sosial Lainnya. Jakarta: Kencana, 2008.

Emir. Metodologi Penelitian Kualitatif: Analisis Data. Jakarta: PT RajaGrafindo Persada, 2012.

Hammad, Nazih. Mu'jam al-Mustalahat al-Iqtisadiyyah fi Lugati al- Fuqaha. Virginia: al-Ma'had al-'Alami li al-Fikri al-Islami, 1995.

Mubarok, Jaih. Wakaf Produktif. Bandung: Simbiosa Rekatama Media, 2008. 
ljtihad, Jurnal Wacana Hukum Islam dan Kemanusiaan, Volume 16, No. 2, Desember 2016: 179-196

Putra, Nusa. Metode Penelitian Kualitatif Manajemen. Jakarta: PT RajaGrafindo Persada, 2013.

Qahaf, Munzir. al-Waqf al-Islami: Tatawwurubu, Idaratubu, Tanmiyyatubu. Damaskus: Dar alFikr, 2006.

Rozalinda. Pengelolaan Wakaf Uang: Studi Kasus pada Tabung Wakaf Indonesia (TWI) Dompet Dhuafa Republika, disertasi tidak dipublikasikan pada Sekolah Program Pascasarjana Universitas Islam Negeri Syarif Hidyatullah, 2010.

Sedarmayanti. Good Governance (Kepemerintahan yang Baik) dan Good Corporate Governance (Tata Kelola Perusahaan yang Baik). Bandung: Mandar Maju, 2007.

Sugiyono. Metode Penelitian Kualitatif, Kuantitatif, dan RひD. Bandung: Alfabeta, 2011.

Usman, Nurodin. Model Pengelolaan dan Pengembangan Bandha Wakaf Masjid Agung Semarang. Disertasi tidak dipublikasikan pada Program Pascasarjana IAIN Walisongo, 2013. 